\title{
NOTES
}

\section{Methanosarcina thermophila sp. nov., a Thermophilic, Acetotrophic, Methane-Producing Bacterium}

\author{
S. H. ZINDER, ${ }^{1 *}$ K. R. SOWERS ${ }^{2}$ AND J. G. FERRY ${ }^{2}$
}

Department of Microbiology, College of Agriculture and Life Sciences, Cornell University, Ithaca, New York $14853,{ }^{1}$ and Department of Anaerobic Microbiology, Virginia Polytechnic Institute and State University, Blacksburg, Virginia 24061 ${ }^{2}$

Methanosarcina thermophila is proposed as a new species name for the thermophilic, acetotrophic, methanogenic bacterum previously designated Methanosarcina sp. strain TM-1, and a formal species description is provided.

The isolation and characterization of thermophilic Methanosarcina sp. strain TM-1 were described previously (2), but a specific epithet was not proposed. The phylogenetic relationships of Methanosarcina sp. strain TM-1 with other methylotrophic methane-producing bacteria were recently determined by deoxyribonucleic acid (DNA)-ribosomal ribonucleic acid hybridization and DNA-
These results clearly indicate that strain TM-1 is a new species in the genus Methanosarcina.

The name Methanosarcina thermophila and the description below are proposed based on previously published information (2) and more recent information on the nutrition of the culture (P. A. Murray and S. H. Zinder, Abstr. Annu. Meet. Am. Soc. Microbiol. 1983 I 8, p. 141). Previously
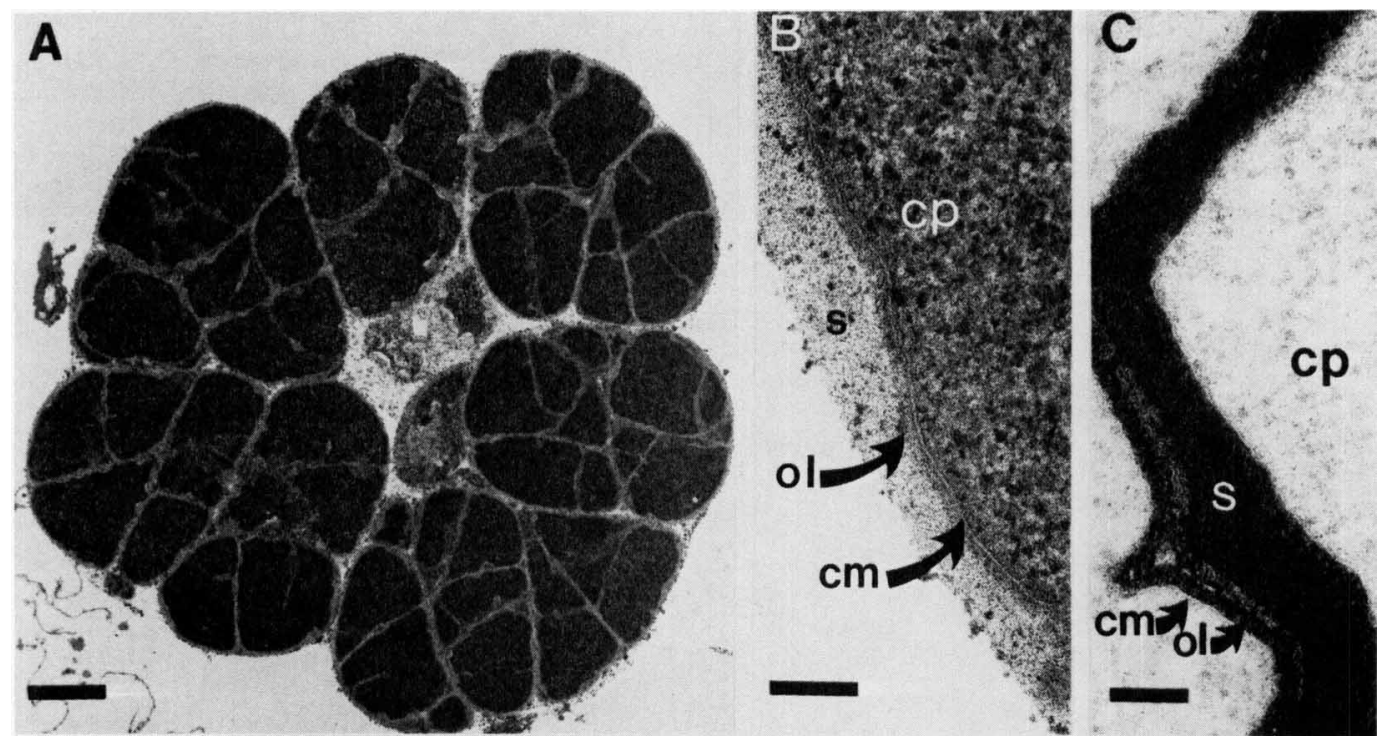

FIG. 1. Thin-section electron micrographs of $M$. thermophila. (A) Cell aggregate showing chaotically dispersed division planes and thick cell sacculus. Cells were fixed in $30 \mathrm{mM}$ PIPES [piperazine- $N, N^{\prime}$-bis(2-ethanesulfonic acid)] buffer (pH 7.0) containing $5 \%$ glutaraldehyde and $4 \%$ formaldehyde, followed by $2 \%$ osmium tetroxide. The fixed cells were embedded in $1.5 \%$ agar and postfixed for $2 \mathrm{~h}$ in $0.5 \%$ uranyl acetate in water. The preparations were then dehydrated with ethanol and embedded in Spurr low-viscosity resin. Thin sections were poststained with saturated uranyl acetate in $70 \%$ ethanol, followed by $0.3 \%$ lead citrate. Bar $=1 \mu \mathrm{m}$. (B) Higher magnification of cells prepared by the same procedure, showing the cell membrane $(\mathrm{cm})$, outer layer $(\mathrm{ol})$, sacculus $(\mathrm{s})$, and cytoplasm $(\mathrm{cp})$. Bar $=0.1 \mu \mathrm{m}$. (C). Area between cells in which some plasmolysis has separated the outer layer from the sacculus. These cells were prepared in the same fashion as those in (B) except that $0.1 \%$ ruthenium red was added along with osmium tetroxide. This caused intense staining of the sacculus and some staining of the outer layer. Bar $=0.1 \mu \mathrm{m}$.

DNA homology (1). The results of this study showed that Methanosarcina sp. strain TM-1 had less than $30 \%$ DNA homology and more than $85 \%$ ribosomal ribonucleic acid homology with all other strains of Methanosarcina tested.

\footnotetext{
* Corresponding author.
}

published phase-contrast micrographs (2) show that the organism exists in large aggregates similar to those of other Methanosarcina strains. Thin-section electron micrographs (Fig. 1) show that $M$. thermophila has chaotically dispersed division planes, which are characteristic of methanosarcinae, and that there is a thick outer sacculus, similar to that of other nonmarine Methanosarcina strains. There also 
is an outer layer 10 to $20 \mathrm{~nm}$ thick just outside the cell membrane. This is in agreement with the proposals of Sowers et al. (1) that both marine and nonmarine methanosarcinae have a thin proteinaceous cell wall layer outside the cell membrane and that in the nonmarine strains this layer is covered by a polysaccharide sacculus, which may provide osmotic protection.

Methanosarcina thermophila sp. nov. Methanosarcina thermophila (ther. mo'phi. la. Gr. adj. thermos hot; Gr. adj. philos loving; N. L. fem. adj. thermophila heatloving) cells are gram positive and spherical and appear as irregular aggregates which are often more than $100 \mu \mathrm{m}$ across and which appear refractile when viewed by phase-contrast microscopy. Colonies in agar are 1 to $3 \mathrm{~mm}$ in diameter and yellow and have a rough granular consistency. Growth occurs on acetate, methanol, or methylated amines and may occur slowly on $\mathrm{H}_{2}-\mathrm{CO}_{2}$. The optimum growth temperature is near $50^{\circ} \mathrm{C}$, and the optimum $\mathrm{pH}$ is between 6.0 and 7.0. The only described strain requires para-aminobenzoic acid for growth. The DNA base composition of this strain is $42 \pm$ 1 mol\% guanine plus cytosine.

Source: $55^{\circ} \mathrm{C}$ anaerobic sludge digestor.

Type strain: strain TM-1 (= DSM 1825).
We gratefully acknowledge T. O. Macadoo, Department of Foreign Languages and Literature, Virginia Polytechnic Institute and State University, for the etymology of the proposed epithet. We also thank W. C. Ghiorse, and D. L. Charbonneau, and R. Garen for assistance with electron microscopy.

\section{ADDENDUM IN PROOF}

A description of the nutrition of Methanosarcina thermophila sp. strain TM-1 has recently been published (P. A. Murray and S. H. Zinder, Appl. Environ. Microbiol. 50: 49-55, 1985).

\section{LITERATURE CITED}

1. Sowers, K. R., J. L. Johnson, and J. G. Ferry. 1984. Phylogenetic relationships among the methylotrophic methane-producing bacteria and emendation of the family Methanosarcinaceae. Int. J. Syst. Bacteriol. 34:444-450.

2. Zinder, S. H., and R. A. Mah. 1984. Isolation and characterization of a thermophilic strain of Methanosarcina unable to use $\mathrm{H}_{2}-\mathrm{CO}_{2}$ for methanogenesis. Appl. Environ. Microbiol. 38: 996-1008. 